\title{
Peripheral nerve and root lesions developing as a result of haematoma formation during anticoagulant treatment
}

\author{
J. D. PARKeS \\ M.D., M.R.C.P. \\ P. H. KIDNER \\ M.R.C.P. \\ Departments of Neurology and Medicine, \\ King's College Hospital, London, S.E.5
}

\begin{abstract}
Summary
Three further cases of peripheral nerve and root lesions occurring during anticoagulant therapy are described. The literature is briefly reviewed.

\section{Introduction}

Peripheral nerve palsies secondary to haematomata developing during anticoagulant treatment are uncommon, and largely confined to the femoral and sciatic nerves. The sudden onset of persistent and frequently agonizing pain of root or nerve distribution, with accompanying corresponding motor and sensory loss, should suggest the possibility of a mishap of this nature. The comparative rarity of these lesions, the importance of differential diagnosis and the possibility of surgical evacuation make it worth while reporting further cases.
\end{abstract}

\section{Case 1}

A 42-year-old breathless lady had the signs of mitral stenosis and incompetence, with a past history of rheumatic heart disease. In 1967 she twice developed features of a deep vein thrombosis in the left leg. A heparin drip (20,000 units 12 hourly) was used on both occasions. On the 2nd day of the second course she experienced the sudden onset of an agonizing pain in the right groin, spreading down the front of the right thigh, and accompanied by a sensation of burning numbness. There was no back pain, no disturbance of bowel or bladder control and no pain or weakness in the left leg. She had multiple bruises on the buttocks, and a tender swelling in the right groin. She was just able to flex the right hip against gravity: extension of the right knee was weak. Sensory impairment was limited to the medial and lower aspect of the left thigh, extending to the inner side of the leg. The knee jerk was absent. Peripheral pulses in both legs were present with no temperature difference between legs. Examination of the CSF was normal. Prothrombin time on the day of the accident was $48 \mathrm{sec}$ (control, $15 \mathrm{sec}$ ).
Weakness of the leg with unbearable burning numbness, continued throughout life. There was considerable depression and no treatment gave significant help; however, irrigation of the spinal theca with ice-cold saline (Hitchcock, 1967) gave partial relief for 10 days. Quadriceps wasting was rapid, and sensory loss permanent. The right knee became stiff, with excess of joint fluid.

The clinical diagnosis was one of haematoma formation around the femoral nerve and roots in the psoas muscle. In view of the patient's general medical state, exploration with a view to evacuation was not thought justifiable. One year after this accident, the patient suddenly died. No necropsy was performed.

\section{Case 2}

In March 1966 a 53-year-old man, following a feverish illness with tiredness and generalized chest pain, developed left calf pain with calf swelling. These latter symptoms resolved only to recur, and at the time of hospital admission, the calf was tender and swollen. There were no clinical or radiological signs of chest disease. ECG showed changes of an old posterior myocardial infarction. Spinal $\mathrm{X}$-rays showed a minor lumbar scoliosis. Anticoagulant treatment was given; with phenindione an average prothrombin time of $26 \mathrm{sec}$ (control, $13 \mathrm{sec}$ ) was achieved. Leg swelling and pain subsided. Some few weeks later a deck chair collapsed beneath him; following this he developed numbness of the lateral border of the left foot. Without further accident he complained 7 days later of the sudden onset of severe pain in the back of the left thigh, with left leg weakness. Considerable spontaneous bruising of the legs, arms and trunk appeared. The left thigh was 1 in. greater in circumference than the right. There was weakness of the left inner and outer hamstrings, dorsiflexors, plantarflexors, invertors and evertors of the ankle and toe flexors and extensors. Power in the hip flexors and adductors was normal, as was that in the glu- 
teal muscles. The left ankle jerk was absent. There was some impairment of light touch sensation over the lateral border of the left foot and fourth and fifth toes, extending posteriorly to the mid-calf. Lumbar movements were full and painless, and lumbar spine X-rays as before showed no significant abnormality. Examination of the CSF was normal, with no evidence of recent intrathecal bleeding. Anticoagulant control, previously good, became uncertain; at the time of the bruising, the prothrombin time was $85 \mathrm{sec}$ (control, $15 \mathrm{sec}$ ). Anticoagulants were stopped.

Leg pain slowly resolved, and 2 months later, there had been a moderate improvement of motor power in the left leg. The ankle jerk remained absent. There were no features of causalgia: the patient could walk with the aid of one stick.

\section{Case 3}

A 65-year-old man was admitted following the sudden onset of severe central chest pain of a few hours' duration. On examination he was seen to be pale, sweating, shocked and drowsy, with an irregular pulse. ECG showed changes of antero-septal infarction. He was treated with infusion of heparin, 20,000 units 12-hourly.

On the 14th day after admission, he was woken at night by a sudden pain in the left groin passing from the left groin to the knee. There was no accompanying backache, or disturbance of bladder control. The next morning the patient complained of weakness of the left leg, with numbness of the left thigh. Several small bruises were visible in the buttock. Heparin was stopped: $12 \mathrm{hr}$ after the accident, prothrombin time was $14 \mathrm{sec}$ (with control $12 \mathrm{sec}$ ). There was marked weakness of left hip flexors and knee extensors. The left knee jerk was lost. There was dense analgesia and anaesthesia on the anterior and medial aspect of the left thigh. No visible groin swelling was present. Over the next 5 days, there was a minimal return of muscle power. Twenty days following admission there was a sudden cardiac arrest: resuscitation was not successful.

\section{Discussion}

No history of backache was given by these patients, making a spinal lesion improbable. The bladder was not affected, and the clinical features were confined to nerve or root distribution.

In Case 1, considerable groin fullness and tenderness, with a painful limitation of hip flexion, was suggestive of retroperitoneal haematoma formation, within the psoas muscle or its sheath, compressing the femoral nerve and roots. In Case 2, the sudden fall cannot be discounted as the cause of a traumatic haematoma or as a provoking cause of a lumbar disc lesion: however, major symptoms appeared suddenly and later, with the appearance of spontaneous skin bruising. No evidence of lumbar disc protrusion, or perispinal haematoma, was given by CSF examination and spinal X-rays. In all cases the catastrophe was heralded by the warning sign of spontaneous skin haemorrhage. This was not so in Case 3 described by Lange (1966); however in this example, there was no definite evidence of anticoagulant medication. The occurrence of spontaneous ecchymoses is perhaps a more reliable warning sign than a poorly controlled prothombin time. In these cases and those described by Lange (1966), Gallois, Dhers \& Badarou (1967) and Prill (1965); prothrombin times have varied from normal to near infinite. Similarly, in cases of peridural spinal haematoma occurring in patients on anticoagulant therapy (Spurny et al., 1964: Strain, 1964)

TABLE 1. Previous case reports of nerve lesions developing during anticoagulant treatment

\begin{tabular}{|c|c|c|c|c|c|c|}
\hline Cases & Nerve & $\begin{array}{c}\text { Muscle } \\
\text { haematoma }\end{array}$ & $\begin{array}{l}\text { Spontaneous } \\
\text { bruising }\end{array}$ & $\begin{array}{l}\text { Prothrombin time } \\
\text { (patient/control) }\end{array}$ & $\begin{array}{c}\text { Haematoma } \\
\text { evacuation }\end{array}$ & Outcome \\
\hline Lange (1966) & $\begin{array}{l}\text { Femoral } \\
\text { Femoral } \\
\text { Femoral } \\
\text { Sciatic }\end{array}$ & $\begin{array}{c}\text { Yes } \\
\text { No } \\
\text { Pelvic } \\
\text { tenderness }\end{array}$ & $\begin{array}{l}\text { Yes } \\
\text { Yes } \\
\text { No }\end{array}$ & $\begin{array}{c}60 \mathrm{sec} \\
26 / 14 \mathrm{sec} \\
\\
50 / 15 \mathrm{sec}\end{array}$ & $\begin{array}{l}\text { No } \\
\text { No } \\
\text { No }\end{array}$ & $\begin{array}{l}\text { Poor } \\
\text { Poor } \\
\text { Poor }\end{array}$ \\
\hline Presse Médicale & Ulnar & Yes & & & & \\
\hline $\begin{array}{l}\text { Pieri \& Pinas (1964) } \\
\text { Levrat cited by } \\
\text { Gallois et al. (1967) }\end{array}$ & $\begin{array}{l}\text { Sciatic } \\
\text { Radial }\end{array}$ & & Yes & & & \\
\hline Gallois et al. (1967) & $\begin{array}{l}\text { Femoral } \\
\text { Lateral } \\
\text { popliteal }\end{array}$ & $\begin{array}{l}\text { Yes } \\
\text { Yes }\end{array}$ & $\begin{array}{l}\text { Yes } \\
\text { Yes }\end{array}$ & $\begin{array}{c}\text { Incoagulable } \\
25 \%\end{array}$ & $\begin{array}{c}\text { No } \\
\text { Evacuation }\end{array}$ & $\begin{array}{c}\text { Poor } \\
\text { Slight improvement }\end{array}$ \\
\hline Prill (1965) & $\begin{array}{l}\text { Sciatic } \\
\text { Sciatic }\end{array}$ & $\begin{array}{l}\text { Yes } \\
\text { Yes }\end{array}$ & $\begin{array}{l}\text { Yes } \\
\text { Yes }\end{array}$ & $30 \%$ & $\begin{array}{c}\text { Evacuation } \\
\text { No }\end{array}$ & $\begin{array}{l}\text { Some improvement } \\
\text { Some improvement }\end{array}$ \\
\hline Present series & $\begin{array}{l}\text { Femoral } \\
\text { Sciatic } \\
\text { distribution } \\
\text { Femoral }\end{array}$ & $\begin{array}{l}\text { Yes } \\
\text { Yes } \\
\text { No }\end{array}$ & $\begin{array}{l}\text { Yes } \\
\text { Yes } \\
\text { Yes }\end{array}$ & $\begin{array}{l}48 / 15 \mathrm{sec} \\
85 / 15 \mathrm{sec} \\
14 / 12 \mathrm{sec}\end{array}$ & $\begin{array}{l}\text { No } \\
\text { No } \\
\text { No }\end{array}$ & $\begin{array}{l}\text { No improvement } \\
\text { Some improvement } \\
\text { Slight improvement }\end{array}$ \\
\hline
\end{tabular}


prothrombin times were not uniformly a guide to impending disaster. In addition to muscle weakness and sensory loss, causalgia may be incapacitating, as in the 17-year-old boy described by Prill (1965) and the lady discussed here (Case 1).

Previously reported cases are summarized in Table 1: the predilection for femoral and sciatic nerve and roots is striking. It would seem probable, as Lange (1966) suggests, that the nerve lesion results from ischaemia due to nerve compression in a tightly swollen muscle. However, recovery has in the majority of cases been poor, even with immediate evacuation of haematoma, and haemorrhagic involvement within the nerve sheath, with involvement of the vasa nervorum, cannot be excluded.

Similarly disappointing results have accompanied laminectomy and removal of spinal compressive haematomata, developing under similar circumstances (Spurny et al.. 1964: Strain, 1964). However, in view of the resulting disability and occasional occurrence of causalgia, the possibility of haematoma formation should be considered, and evacua- tion done if feasible, in patients on anticoagulant treatment developing a sudden nerve or root lesion.

\section{Acknowledgments}

We wish to thank Dr Hugh-Jones, Dr S. Oram and Dr N. Lloyd Rusby for allowing us to study these cases.

\section{References}

Gallois, P., Dhers, A. \& Badarou, G. (1967) Deux cas de paralysie nerveuse peripherique par hamatome spontane au cors de traitement anticoagulant. Lyon médical, 218, 401.

HiтcHCock, E. (1967) Hypothermic subarachnoid irrigation for intractable pain. Lancet, i, 1133.

LANGE, L.J. (1966) Lower limb palsies with hypoprothrombinaemia. British Medical Journal, 2, 93.

Pieri, J. \& Pinas, E. (1964) Un cas de paralysie sciatique. Marseille-médical, 101.2, 131.

PrILl, A. (1965) Ischiadicus Lähmungen als komplikation unter anticoagulantienbehandlung. Medizinische Welt (Stuttgart), 6, 307.

SPURNy, O.M., Rubin, S., Wolf, J.W. \& Wu, W.Q. (1964) Report of two cases of spinal epidural haematoma during anticoagulant treatment. Archives of Internal Medicine, 114, 103.

STRAIN, R.E. (1964) Spinal epidural haematoma in patients on anticoagulant therapy. Annals of Surgery, 159, 507. 